\title{
Greening of Public Spaces in Cherepovets during Urbanization, 1870 - 1930s: Contradictions of Sustainable Development
}

\author{
Anna B. Agafonova ${ }^{1}$
}

\begin{abstract}
From the second half of the XIX century, public gardens and boulevards have become an integral part of provincial Russian towns. They played an aesthetic and sanitary-hygienic role in urban space, being, in fact, green oases in a dusty and noisy town. However, in the XX century, the functional purpose of town gardens has changed: the recreational component is being replaced by the cultural and entertainment one, which became dominant in the Soviet period. This article considers the process of urban space greening in the provincial town of Cherepovets as an example of this process and transforming the functions of the town garden. It also presents the analysis of everyday practices of using urban flora by the population of Cherepovets. The methodological basis of the work is urban environmental history. The research is based on archival and office materials, official statistics, and periodicals. Soviet power kept the tradition of new blocks greening, that formed in the prerevolutionary period. At the same time, the entertainment and leisure functions of the recreation park supplanted the recreational function, and everyday practices of the town residents showed a dismissive and utilitarian attitude towards the town green spaces. It was due to the peculiarities of urbanization in the city. In the conditions of the constantly expanding town space and the influx of rural population, green spaces could not prevent the degradation of the natural environment, which led to the destabilization of the ecological situation in Cherepovets and prevented the sustainable development of the city.
\end{abstract}

Keywords: urban environmental history, urban greening, a city garden, everyday practice

\section{Introduction}

Gardening is an important element of the sustainable development of the town. Public parks, gardens, boulevards create a favorable environmental situation in the town, supporting biodiversity and reducing noise and air pollution. In addition, they act as platforms for social communication of citizens, a leisure place for various social groups. The town greening practices span a century and originated long before the sustainable development concept. Public gardens, parks, boulevards were an important part of Russian cities of the XIX - early XX centuries. Their cultivation allowed to meet the aesthetic needs of the population and arrange recreational areas within the cities. In small provincial towns of the Russian Empire, park culture began to develop in the second half of the 19th century, although house gardens existed long before. The greening of small Russian towns chronologically coincided with the time of urbanization beginning and the intensive expansion of urban space due to the influx of rural population. These processes reflected the interaction of the citizens with the natural environment that took place in specific historical socio-economic conditions, and, accordingly, they are of particular 
research interest in the context of sustainable urban development. As for Russian towns of the last third of the XIX - beginning of XX centuries, it also resulted from the facts that, firstly, during this period there was a transition from a capitalist economy to a planned one, and, secondly, the urban space was expanding significantly.

This study considers the role of green spaces in the sustainable development of Cherepovets town by analyzing urban landscaping practices and the use of green spaces by the citizens. Before the revolution of 1917, Cherepovets was the administrative center of the Cherepovets district of the Novgorod province, and from 1918 to 1927 - the administrative center of the Cherepovets province. Later it became a district center, first, in the Leningrad and then in the Vologda regions. At the beginning of the XX century the town became a major transport hub located at the Northern Railway and being a part of the Mariinsky Water System which connected St. Petersburg with the towns of the Volga region. Since the end of the XIX century, an intensive influx of rural population into Cherepovets town was observed, mainly due to the development of transport routes: the modernization of the Mariinsky water system and the construction of the Northern Railway section connecting Vologda, Cherepovets and St. Petersburg. In the period from 1878 to 1939 , the number of the citizens increased by almost 10 times: from 3809 to 32353 people (Materialy po issledovaniju, opisaniju i statistike Novgorodskoj gubernii, 1880; Chislennost' naselenija SSSR na 17 janvarja 1939 goda, 1941, p. 29).

The history of town greening, the emergence and development of national and state parks is widely represented in foreign studies (Brantz, 2011; Elliot, 2016; Jonnes, 2016; Landrum, 20040; Rosenzweig, 19920). In Russian historiography, the following works are worth highlighting: O. Yu. Elina (2008) on the history of agricultural experimental institutions, as the author described the transition of private gardens to experimental stations and fields in the XVIII - first half of the XIX centuries; K. Kuher (2012) on the history of the Gorky central recreational park and the place of the park in the town residents' leisure culture of the of the Stalin period0; L. A. Myasnikova and N. L. Shaigardanova's monography "Soviet Eden" (2016) studying the phenomenon of the Soviet recreational park in the context of the development of Soviet culture and ideology, as a link to the cultural and historical transformation of Russian garden and park ensembles. At the same time, the history of the formation and practice of everyday use of town parks and other provincial recreational areas in the second half of the XIX the first half of XX centuries were insufficiently studied. As for Cherepovets, the history of its landscaping in the context of the town' socio-economic development is most fully represented in the work of K.D. Krendelev (1996) "Cherepovets greening", and the history of the town park - in the work of E.E. Shulyatikova (1999).

This article contributes to the investigation of the aspects of the town' greening history and revealing the daily practices of using town gardens and boulevards. The methodological basis of the work is urban environmental history, which allows studying the town greening process and everyday use of green public spaces as the interaction of nature and society, which determines the sustainability of urban development. The study is based on the materials of the Russian State Historical Archive and the archive of the Cherepovets Museum Association, official statistics, office records, and periodicals. 


\section{Urban Greening in Cherepovets, $1870-1930$ s}

In Cherepovets in the middle of the XIX century, there were two private orchards: in Petrovskaya street and at the intersection of Krestovsky Lane, Embankment and pasture land. On Sobornaya Gorka there was an English garden adjacent to the Voskresensky Monastery eastern border; another English garden was located in Petrovskaya street (Arhiv Cherepoveckogo muzejnogo objedinenija (Arhiv CherMO). F. 13. Op. 1. D. 1., sh. 101). The further arrangement of public gardens, parks and boulevards was associated with the activities of the mayor I.A. Milyutina. According to the City Regulation of 1870, the urban improvement issues, including the arrangement and maintenance of the town gardens and streets, were the town public administration responsibility (Gorodovoe polozhenie0, 1892, p. 1 - 15). In the 1860s and 1870s, Cherepovets was actively growing, new blocks were being constructed. In 1873 a new town plan was officially approved, according to which the street separating the old blocks from the new ones in the western part of Cherepovets was decides to be rearranged into a boulevard in the name of Aleksandrovsky Avenue - in honor of "His Imperial Highness Sovereign of the heir Tsesarevich, as a high patron of the Alexander Technical School" (Rossijskij gosudarstvennyj istoricheskij arhiv. F. 1287. Op. 40. D. 1364, sh. 1). In addition, as a result of Cherepovets plan consideration drawn up by the town government, the city council recognized the need for greening of the territory between the cemetery and the town in order to separate the territory of the cemetery from the urban development (Ibid., sh. 3 b.).

Also, by the Town Council resolution, a 3343 square meters plot, located in the 51st block behind the vocational school, was meant to be used partially for botanical and outdoor gardens, as well as for vegetable gardens (Ibid., sh. 3 b.). The construction of the Milyutinsky Square (later the garden) dates back to the same time. Approximately at the same time, in 1880s, the Salt Garden was arranged (Shuljatikova, 19990, p. 481 - 492). The fact that in the pre-revolutionary period they were two separate public spaces, was mentioned by the local press, which published the results of the City Council meeting, where these objects appeared as adjacent, but not identical to each other (Severnyj torgovyi posrednik, 1912, № 1).

The construction of the Salt garden (a city park) was carried out on a plot of land that belonged to M.I. Lentovskaya, the daughter of A.I. Milyutin, where previously there had been salt warehouses, which gave the name to the garden. According to the initial plan, the Milyutinsky garden was a botanical site, which served to acclimatize the plants growing in it, but the Salt garden was meant by I.A. Milyutin as a place for recreation and entertainment of the town residents. The new garden plan draft was commissioned to be developed by N.I. Bernik, a Polytechnic Institute student, who was exiled for the membership in "Narodnaya Volya" ("People's Freedom") movement to Cherepovets (Krendelev, 1996, p. 337 - 338). As noted by K.D. Krendelev, the foundation of the park was laid - it was a ring alley of poplars with radially diverging rays of paths (Ibid., p. 338). Willows, birches, lindens, elms, maples, oaks, and fir trees were also planted in the garden. As for the bushes, spirea (several species), cotoneaster, lilac (common and Persian), derain (Siberian and common), elderberry, viburnum, hazel and roses were also planted. In addition, seedlings from Riga, St. Petersburg, the Volga region, Siberia were brought into 
the garden, that made it possible to collect more than one hundred tree species in one place (Ibid., p. 340).

In the 1880s the construction of boulevards on Alexandrovsky pr. started (Arhiv CherMO. F. 13. Op. 1. D. 1, sh. 101). Different tree species were planted in every boulevard block. From the Salt garden to Treasury lane there was a linden alley, and a willows alley up to Krestovsky street, followed by the alley of elm, ash and linden in Sadovaya st. Between Sadovaya street and Korzhevsky lane there was a birch boulevard with deciduous trees, which stretched up to Popovskaya street (Fedosyevskaya st.), and a maple alley, following it up to Zavodskaya Street (Ibid., sh. 105). In the 1890s Northern boulevard and a female vocational school's garden for educational and practical purposes were arranged (Ibid., sh. 101).

At the beginning of the XX century in Cherepovets, $11.2 \%$ of the streets were landscaped, and the town garden occupied 1.9\% of the town's area (Goroda Rossii, 1906 , p. 5-9), the area of both public gardens reached $3.5 \mathrm{~d}$. The length of Alexandrovsky and Northern boulevards was 2 "versts" (1,3 miles) and 290 "sazhens" (0,38 miles) (Cherepovec v nachale XX veka, 1996, p. 287 - 298). In addition, as noted by E.E. Shulyatikova, by 1901, the Salt town included the boulevard from Sergievsky lane up to Nikolskoye road, and the boundary line coincided with the southwestern border of the garden (Shuljatikova, 1999, p. 481 - 492). By 1902, a garden near the Istochnitskaya chapel on the banks of the Yagorba river, a garden near the railway station, a town farm, and the Pokrovskoye cemetery were arranged and landscaped (Materialy dlja ocenki gorodskih nedvizhimyh imushhestv0, 1902, p. 137). Also, under I.A. Milyutin rule, from Vereshchagins' house down to the Yagorba river, an oak-linden alley was planted, and the area around the Alexander Technical School was planted with larch, oaks, willows and lindens (Krendelev, 1996, p. 341). Despite the relatively small area of public gardens, the town residents found the town to be cozy and green. In particular, the song folklore collector E.E. Livneva spoke of Cherepovets as a of small town that was buried "in the greenery of gardens and boulevards, almost without pavements, with wooden clutches instead of sidewalks (Dokumentova, Teterkina, 1996, p. 299-303).

In the Soviet period, Alexandrovsky boulevard, which was renamed Lunacharsky avenue and stretched from Volodarsky street (former Zavodskaya street) to Halturin street, was surrounded by lindens (Arhiv CherMO. F. 13. Op. 1. D. 1, sh. 105). In 1934 the trees were planted and the boulevards were equipped with new $2500 \mathrm{~m}$. fences (Otchet Cherepoveckogo gorodskogo Soveta, 1934, p. 14). In 1935, a boulevard in Volodarskaya street was planted with birch and linden trees (Arhiv CherMO. F. 13. Op. 1. D. 1, sh. 101, 105), and a poplar alley was planted near the distillery (Ibid., sh. 105). In the 1930s there were 24 gardens in the town, the largest ones were the recreational garden (the former Salt garden) and the garden on the Cathedral Hill. There were also gardens at the pedagogical college, at the railway station, at elementary school № 6, at the town stadium, at the Forestry and Mechanical College. A linden alley and a linden garden were planted at the dispensary (Ibid., sh. 105). Greening of the following new town streets was carried out: Zarya Svobody st., Vologodskaya st., Zheleznodorozhnaya st., Pionerskayast., Krasny Pereulok (Krendelev, 1996, p. 343). By 1934 the total area of green spaces in the city was 25.2 hectares (Otchet Cherepoveckogo gorodskogo Soveta, 
1934, p. 14).

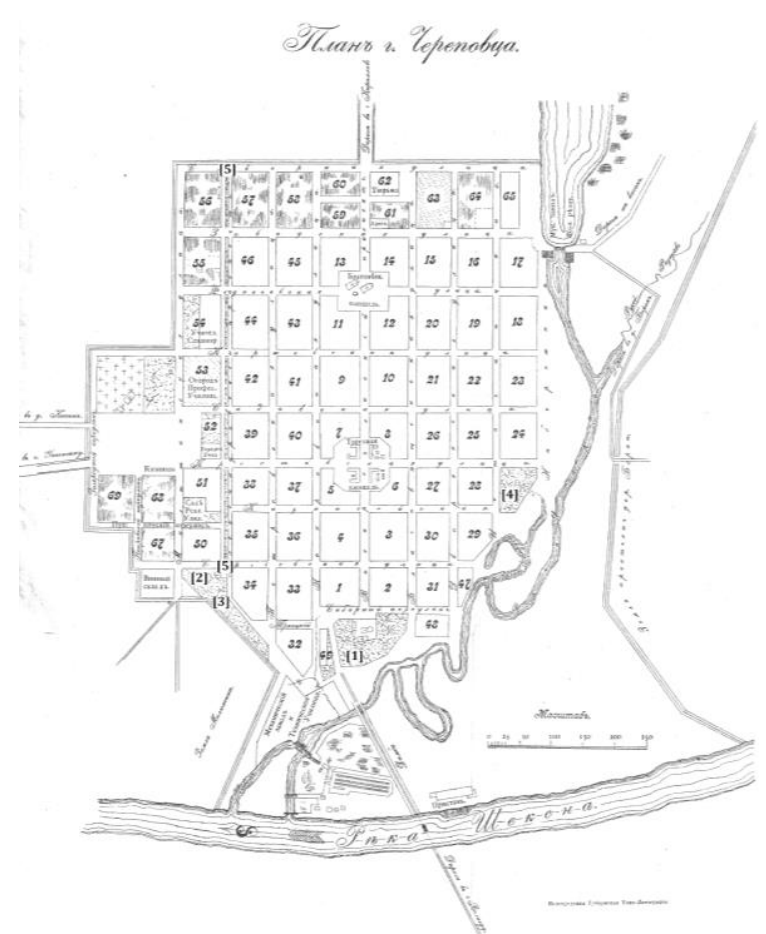

Figure 1. The main green public places of Cherepovets at the beginning of the 20 $0^{\text {th }}$ century: [1] - the English garden on Sobornaya Gorka, [2] - Milyutinsky Garden, [3] - Salt garden, [4] - the garden near the Istochnitskaya chapel, [5] - Alexandrovsky boulevard. Source: Plan of Cherepovets town // Materials on the urban real estate assessment of the Novgorod province. Volume VII. Cherepovets. Novgorod: A.I. Shcherbakov's Steam Printing House, 1902.

\section{Exploitation of Green Public Places in Cherepovets}

According to N.L. Shaygardanova (2018), in the XX century urban landscape culture, two trends stood out, which in practice were often combined within the framework of one park type (a garden). First of all, this is the arrangement of parks as walking green islands among the urban stone jungle and, secondly, the arrangement of amusement parks with many attractions and other forms of the town residents' leisure. The first trend prevailed in the provincial towns in the pre-revolutionary period and was partly due to the attempts to improve their sanitary condition. In particular, in the provincial towns close to Cherepovets - Novgorod and Vologda, green spaces were perceived as oases among a noisy and dusty town that could somewhat mitigate the effects of regular pollution of territories. The sanitary doctors often called for more extensive greening of towns, since there were not enough gardens and boulevards (Kurkutov, 1915, p. 18; Ornatskij, 1888, p. 47).

In the pre-revolutionary period in Cherepovets there was a clear functional division of the town recreational areas. It can be clearly traced on the example of the Milyutinsky garden and the Salt town. The garden was a quiet place for walks and rest of the town 
residents (Ja.A., 1912), concerts and various social events were also held in the Salt town. The performances and dancing were organized there, the performer of gypsy romances and Russian songs E.V. Valevskaya gave concerts there (Mestnaja hronika, 1912, №№ 4, 6). As noted by E.E. Shulyatikova (1999), in 1890 a gazebo for brass bands was built in the Salt town. In 1892 a two-story wooden theater building and in 1910 a summer cinema, turned the town into a leisure center for its residents. In the early 1910s the Salt town was bought out by a group of shareholders who repaired it: the new owners added canopies and balconies to the Salt town buildings from the side of Milyutinsky Garden (Ja.A., 1912).

In May 1912, a petition was submitted to the Town Duma for the opening of a cinema hall in the Salt town building and a request from the First Public Assembly for the allocation of a part of the Milyutinsky Garden adjacent to the Salt town, which the Assembly had already partially removed and fenced. Both petitions were rejected by the Town Council (Gorodskaja zhizn', 1912). However, this did not prevent the First Public Assembly from moving the furniture, billiards and the buffet to a rented plot in the Salt town, and to celebrate housewarming on 3 June there (Ja.A., 1912). This event caused discontent among the concerned town residents, who condemned noisy meetings with proposing toasts and loud music, which broke the silence and tranquility of the garden and were a bad example for children and teenagers walking in the garden (Ibid.). As for the Milyutinsky garden, a small pavilion was built to sell ice cream, sweets and soft drinks. However, it lacked even the most primitive facilities, like open grooves, to divert drains from the pavilion, that's why the employees had to pour slops onto the nearest garden paths or the outer walls of the pavilion (Severnyj torgovyj posrednik, 1912, №. 6.).

Alexandrovsky boulevard was a favorite place for the walking town residents, who were walking from the theater to the garden or from the garden to the town. At the same time, poor illumination of the boulevard part between the Salt town and the vocational school made these walks rather dangerous, since the boulevard attracted not only decent people, but also drunkards of both sexes (Severnyj torgovyj posrednik, 1913, №. 32.).

In the Soviet period, the Salt town and the Milyutinsky garden were transformed into the Garden of Culture and Rest. Attractions were arranged there to draw the attention of the town residents. In the 1930s the park was expanded with a fountain, a playground, additional arbors and new lawns (Kogda budet otkryt sad kul'tury i otdyha?, 1938, p. 4; Sad kul'tury i otdyha otkryvaetsja 21 maja, 1938, p. 4). In the late 1930s the Garden of Culture and Rest was one of the most significant leisure centers for the town dwellers in the warm seasons. At the weekend, the number of visitors could reach 4000 people and even more. In summer, morning and evening performances were held in the garden, dancing and children's playgrounds, attractions, including carousel, shooting gallery, swing for children, volleyball court invited the visitors (Sad kul'tury i otdyha otkryvaetsja 21 maja, 1938, p. 4). In addition, checkers and chess matches were held there among the Cherepovets and Vologda athletes, who fought for the championship in the Vologda region (Shahmatno-shashechnyj match Vologda - Cherepovec, 1938, p. 4; Shahmatnyj turnir, 1938, p. 4).

However, as the mass entertainment culture penetrated public gardens, the role of urban green spaces was devalued, the perception of these public spaces as green oases in a 
noisy town was replaced by a utilitarian attitude to gardens as entertainment places. In Cherepovets, there were several cases of vandalism in the boulevards and gardens. In particular, in the fall - winter period of 1937 - 1938 on Volodarsky boulevard some unknown people cut down most of the trees, so, in the spring of 1938 more than 20 new trees were planted. In general, on Lunacharsky and Volodarsky boulevards, many trees were broken, the young trees binding was cut off, the stakes were stolen. By the spring of 1938, near the bathhouse № 2, only 4 of 16 planted trees had survived (Barinov, 1938, p. 3). The most large-scale act of vandalism was committed on the 4 hectares area in the new part of the Garden of Culture and Rest in July 1938. The enclosure of that garden part, which was done on June 26 by the Town Council, was connected with the USSR Supreme Soviet elections. The blooming roses and Persian lilacs, which had been planted in that part of the garden, were torn out on the very first day, not only by children, but also by adults, who were trampling freshly planted lawns (Ibid., p. 3).

A valuable source for the study of using the town garden, park and boulevard zones in the 1930s is a note written by Mikhail Evgenievich Kalinin, the executive secretary of the Cherepovets Regional Studies Bureau. The note was kept in the funds of the Cherepovets Museum Association, and dates back to 1936 (Arhiv CherMO. F. 25. Op. 1. D. 263. Ed. hr. 4'10.). M.E. Kalinin noted that Cherepovets was the best town in the region in terms of the quantity of green spaces, while the safety of the boulevards and gardens was "on the lowest level" (Ibid., sh. 1). In the Garden of Culture and Rest, all the lawns were damaged, and the lawn near the summer theater was a bare, densely packed area with mutilated tree roots. A similar state of vegetation and soil was observed near the dance floor, attractions and carousels. By 1936, behind the theater building, the fir trees which were rare for Cherepovets, perished; in the park deciduous trees dried up, the trees on boulevards were destroyed by people and livestock (Ibid., sh. 1 b.). From the very first days and weeks the work on the park expanding and planting new trees was accompanied by damaging the trees, cutting or breaking tops (Ibid., sh. 1 b.). That was confirmed by the data on the natural conditions of the planning and construction territory of the Cherepovets district, as it was indicated that up to $40-50 \%$ of trees were damaged in some parts of Lunacharsky avenue (Arhiv CherMO. F. 13. Op. 1. D. 1. sh. 105). The concern over the protection of green spaces was expressed at the Cherepovets Town Council of workers, peasants and Red Army deputies of the VIII convocation (Otchet Cherepoveckogo gorodskogo Soveta, 1934, p. 14).

Mikhail Evgenievich noted that “people don't think at all, walk where they want without being stopped, build rides and stalls, completely ignoring how and to what extent this can affect the trees" (Arhiv CherMO. F. 25. Op. 1. D. 263. Ed. hr. 4'10, sh. 1). To a separate category of Cherepovets flora violators, he referred communication workers who chopped down "a huge number of trees" (Ibid., sh. 2). Moreover, the complaints on their activities to the Town Council Presidium did not give any result - they continued to destroy trees for laying communication lines. M.E. Kalinin pointed out that it was a habit for Cherepovets citizens to walk and run around the lawns, climb trees, break their branches and peaks, peel the bark, make cuts, pull out the trees with their roots and chop them with axes (Ibid., sh. 2). No less damage was caused by the livestock that walked along the boulevards and was grazed in the town. According to M.E. Kalinin, in autumn and spring, horse-drawn vehicles were widely used, despite the fact that the goats often 
stroked the town trees, and hundreds of horses tied to the trees, harmed the trees root system with their feces (Ibid., sh. 2-2 b.). To the remarks addressed to the tree violators or their livestock, they reacted very violently with indignation, being assured in the rightness to observe old traditions (Ibid., sh. 2). M.E. Kalinin wrote: "we were overwhelmed by tradition, philistinism, pre-revolutionary past of the hooligan town, $<\ldots>$ we have too many indifferent people, quietly passing by these outrages. We still do not have enough of those who hate these outrages, capable of waging a decisive struggle for a cultural green town" (Ibid., sh. 2 b.).

Such attitude of the town residents towards the urban flora was explained, on the one hand, by the fact that in Cherepovets, the perception of parks and gardens as green oases in the middle of a noisy town, intended for rest and walks, did not take root among the majority of town residents. Ever since the pre-revolutionary time, the town garden (Salt town) attracted the town residents with its cultural program, the opportunity to attend mass entertainment events, which in the Soviet period became even more diverse and focused on different age groups of the population. On the other hand, the late imperial and Soviet urbanization was characterized by the phenomenon that S.P. Hays (1998) called "the transfer of social practices that have long been established in the countryside to new places with a more concentrated population". New residents arriving in Cherepovets reproduced close to them, traditional for their social environment practices of using urban space. Urban green spaces were perceived by yesterday's peasants as a natural habitat, but not as a decoration of the urban environment.

\section{Conclusion}

Thus, in the pre-revolutionary period, the main recreational landscape zones of the town were laid. They were situated on the river banks and in the town suburbs. The tradition of newly built blocks greening continued in the Soviet period. At the same time, the main green array was concentrated along the Sheksna river banks, in the Cathedral Hill area, Salt town, Milyutinsky Garden (Garden of Culture and Rest) and Alexandrovsky boulevard (Lunacharsky pr.). The abundance of green spaces allowed the contemporaries to call Cherepovets a garden town (Novikova, 1999). However, the practice of using town boulevards and gardens, shows that the town residents perceived the trees, bushes and flowers growing in them as elements of the natural environment, which should be utilitarian. This was also facilitated by the functional definition of the main town park - the Garden of Culture and Rest, as an entertainment and leisure center for the citizens with many attractions, a theater, a children playground and a dance floor. From the urban development sustainability point of view, it should be noted that in both in the late Imperial and Soviet periods, the policy of the city authorities regarding new blocks regular greening and the town garden expansion indicates a desire to improve the sanitary and environmental state of Cherepovets. In the ever-expanding town space, the green spaces were supposed to prevent the natural environment degradation of the urban suburbs. However, the practice of using them by the town residents showed that in fact they did not fulfill this task due to their rapid destruction or damage. Accordingly, the intensive influx of rural population into the town led to destabilization of the environmental situation in Cherepovets, which impeded the sustainable development of 
the town.

\section{Acknowledgment}

The work was done with the joint financial support of the Russian Foundation for Basic Research and the Government of Vologda Region, grant number 18-49-350002 r_a

\section{References}

Arhiv Cherepoveckogo muzejnogo objedinenija (Arhiv CherMO) [Archive of Cherepovets Museum Association (CherMA Archive)]. F. 13. Op. 1. D. 1. Estestvennye uslovija planirovochnostroitel'noj territorii rajona goroda Cherepovec [Natural conditions of planning and construction of the Cherepovets district territory.].

Arhiv CherMO [Archive CherMA]. F. 25. Op. 1. D. 263. Ed. hr. 4'10. Kalinin M. Pora prekratit' bezobrazija [Kalinin M. It's time to stop the disgrace]. 4/XI/36 g.

Barinov Berech' zelenye drevonasazhdenija [To protect green plantations]. Kommunist [Communist]. 1938. № 169. L. 3.

Brantz D., Dümpelmann S., Valenzuela-Aguilera A. Greening the City: Urban Landscapes in the Twentieth Century. Charlottesville: University of Virginia Press, 2011. 246 p.

Cherepovec v nachale XX veka [Cherepovets at the beginning of the XX century]. Cherepovec: Kraevedcheskij al'manah [Cherepovets: local history almanac]. Vologda: Rus', 1996. pp. 287 - 298.

Chislennost' naselenija SSSR na 17 janvarja 1939 goda. Po rajonam, rajonnym centram, gorodam, rabochim poselkam i krupnym sel'skim naselennym punktam [The population of the USSR on January 17, 1939 by districts, district centers, cities, workers' settlements and large rural settlements]. M.: GOSPLANIZDAT, 1941. 266 p.

Dokumentova, N.T., Teterkina, V.V. Pis'ma iz Cherepovca [Letters from Cherepovets]. Cherepovec: Kraevedcheskij al'manah [Cherepovets: local history almanac]. Vologda: Rus', 1996. pp. 299 - 303.

Elina O.Ju. Ot carskih sadov do sovetskih polej: Istorija sel'skoborjajstvennyh opytnyh uchrezhdenij XVIII - 20-e gody XX veka: $\mathrm{v} 2 \mathrm{~h}$ tomah. T.1. [From tsarist gardens to Soviet fields: The history of agricultural experimental institutions of the 18th - 20th years of the 20th century: in 2 volumes]. M.: Jegmont Rossija Ltd., 2008. 478 p.

Elliot P.A. British Urban Trees: a social and cultural history, c. 1800 - 1914. Winwick: White Horse Press, 2016. 407 p.

Goroda Rossii [Cities of Russia]/ Centr. stat. kom. MVD. SPb.: Tipo-lit. Nyrkina, 1906 - 1914. 2 t. T. 1: Goroda Rossii v 1904 godu [Cities of Russia in 1904]. 1906. 907 p.

Gorodovoe polozhenie s zakonodatel'nymi motivami, raz\#jasnenijami i dopolnitel'nymi uzakonenijami [City regulation with legislative motives, explanations and additional legalizations]. Sost. S.G. Shheglovitov. SPb.: Tip. M.M. Stasjulevicha, 1892. 736 p.

Gorodskaja zhizn' [City life]. Severnyj torgovyj posrednik [Northern Reseller]. №1. 1912.

Hays S.P. Explorations In Environmental History. Pittsburgh: University of Pittsburgh Press, 1998. 480 p.

Ja.A. V chuzhom piru pohmel'e [A hangover in a strange feast]. Severnyj torgovyj posrednik [Northern Reseller]. 1912. № 4.

Jonnes J. Urban Forests: A natural history of trees and people in the American cityscape. New York: Viking, 2016. $394 \mathrm{p}$.

Kogda budet otkryt sad kul'tury i otdyha? [When will the garden of culture and rest be opened?]. Kommunist [Communist]. 1938. № 91. pp. 4.

Krendelev K.D. Zelenyj narjad Cherepovca [Cherepovets greening]. Cherepovec: Kraevedcheskij al'manah [Cherepovets: local history almanac]. Vologda: Rus', 1996. pp. 333 - 348.

Kuher K. Park Gor'kogo. Kul'tura dosuga v stalinskuju jepohu, 1928 - 1941 [Gorky Park. Leisure culture in the Stalin era]. M.: ROSSPJeN, 2012. 350 p.

Kurkutov A.G. $V$ oblasti sanitarii $i$ blagoustrojstva Velikogo Novgoroda [In the field of sanitation and improvement of Veliky Novgorod]. Novgorod: Gubernskaja Tipografija, 1915. 33 p.

Landrum C. The State Park Movement in America. Columbia: University of Missouri press, 2004. 288 p. 
Materialy dlja ocenki gorodskih nedvizhimyh imushbestv Novgorodskoj gubernii. Tom VII. g. Cherepovec [Materials on the urban real estate assessment of the Novgorod province. Volume VII. Cherepovets]. Novgorod: Parovaja Tipografija A.I. Shherbakova, 1902. 137 p.

Materialy po issledovaniju, opisaniju i statistike Novgorodskoj gubernii [Materials on the research, description and statistics of the Novgorod province]. Pamjatnaja knizhkea Novgorodskoj gubernii na 1880 god [Memory book of the Novgorod province on 1880]. Novgorod: Tip. Novgor. Gub. Pravl., 1880. pp. 60 - 63.

Mestnaja hronika [Local chronicle]. Severnyj torgoryj posrednik [Northern Reseller]. №4. 1912

Mestnaja hronika [Local chronicle]. Severnyj torgovyj posrednik [Northern Reseller]. №6. 1912.

Mjasnikova L.A., Shajgardanova N.L. Sovetskij Jedem: monografija [Soviet Eden: monography]. Ekaterinburg: Gumanitarnyj universitet, 2016. 209 p.

Novikova N.I. Iz vospominanij cherepoveckogo starozhila: Gorod moego detstva (Cherepovec v 1930-e gody) [From the memoirs of the Cherepovets old-timer: City of my childhood (Cherepovets in the 1930s)]. Cherepovec: Kraevedcheskij al'manah. Vyp. 2 [Cherepovets: local history almanac. Vol. 2]. Vologda: "Legija", 1999. pp. 70 - 87.

Ornatskij V.I. Medikotopografija. Sanitarnoe sostojanie gubernskogo goroda Vologdy: diss. d. mediciny [Medicotopograhpy. The sanitary condition of the provincial city of Vologda]. SPb.: Tip. Departamenta Udelov, 1888 g. 196 p.

Otchet Cherepoveckogo gorodskogo Soveta rabochih, krest'janskih i krasnoarmejskih deputatov VIII sozyva trudjashhimsja goroda za 1931 - 1934 god [Report of the Cherepovets Town Council of Workers, Peasants and Red Army Deputies of the VIII convocation to the town workers in 1931 - 1934]. Cherepovec, 1934. 25 p.

Rosenzweig R., Blackmar E. The Park and the People: A History of Central Park. Ithaca: Cornell University Press, $1992.600 \mathrm{p}$.

Rossijskij gosudarstvennyj istoricheskij arhiv (RGIA) [The Russian State Historical Archive (RSHA)]. F. 1287. Op. 40. D. 1364. O prisvoenii ulic i predlozhennomu $\mathrm{k}$ ustrojstvu bul'vara $\mathrm{v}$ gorode Cherepovce Naslednika cesarevicha [On Heir to the Crown Prince's street naming and the proposed construction of the town boulevard in Cherepovets], 1873.

Sad kul'tury i otdyha otkryvaetsja 21 maja [The Garden of Culture and Rest opens on May 21]. Kommunist [Communist]. 1938. № 113. p. 4.

Sad kul'tury i otdyha v vyhodnoj den' [Garden of Culture and Rest on the day off]. Kommunist [Communist]. 1938. № 160. p. 4.

Severnyj torgovyj posrednik [Northern Reseller]. 1912. № 1.

Severnyj torgoyjj posrednik [Northern Reseller]. 1912. №. 6.

Severnyj torgovyj posrednik [Northern Reseller]. 1913. № 32.

Shahmatno-shashechnyj match Vologda - Cherepovec [Vologda - Cherepovets Chess and checker match]. Kommunist [Communist]. 1938. № 160. p. 4

Shahmatnyj turnir [Chess tournament]. Kommunist [Communist]. 1938. № 170. p. 4.

Shajgardanova N.L. Perspektivy razvitija gorodskogo parka (sada) kak fenomena kul'tury [Prospects for the development of a town park (garden) as a cultural phenomenon]. Sad v gorode: budni i prazdniki. Sbornik materialov mezhdisciplinarnogo seminara [Garden in the city: weekdays and holidays. Collection of materials of interdisciplinary workshop]. Pskov: Pskovskij gosudarstvennyj universitet, 2018. pp. $37-45$.

Shuljatikova E.E. Istorija gorodskogo parka (Soljanogo sada) [History of the town park (Salt garden)]. Cherepovec: Kraevedcheskij al'manah. Vyp. 2 [Cherepovets: local history almanac. Vol. 2]. Vologda: "Legija", 1999. pp. 481 - 492. 